\title{
Acetylcholinesterase and Cytotoxic Activity of Chemical Constituents of Clutia lanceolata Leaves and its Molecular Docking Study
}

\author{
Mehtab Parveen - Faheem Ahmad - Ali Mohammed Malla • \\ Shaista Azaz • Mahboob Alam • Omer A. Basudan • \\ Manuela Ramos Silva • Pedro S. Pereira Silva
}

Received: 8 September 2016/Accepted: 8 October 2016/Published online: 18 October 2016

(C) The Author(s) 2016. This article is published with open access at Springerlink.com

\begin{abstract}
Phytochemical investigations of the ethanolic extract of leaves of Clutia lanceolata (Family: Euphorbiaceae) resulted in the isolation of four compounds viz. 3,4-dihydroxy-2-methylbenzoic acid (1), 2,2'-dihydroxy-1,1'-binaphthyl (2), 1,3,8-trihydroxy-6-methylanthracene-9,10-dione (3) and 5-hydroxy-1,7-bis(4-hydroxy-3-methoxyphenyl)hepta-1,4,6trien-3-one (4). Although all the isolated compounds were known but this was the first report from this plant source. Their structures were established on the basis of chemical and physical evidences viz. elemental analysis, FT-IR, ${ }^{1} \mathrm{H}-\mathrm{NMR},{ }^{13} \mathrm{C}$ NMR and mass spectral analysis. Structure of compound $\mathbf{2}$ and $\mathbf{4}$ was further authenticated by single-crystal X-ray analysis and density functional theory calculations. The isolated compounds (1-4) were screened for AChE enzyme inhibition assay in which compound $\mathbf{3}$ and $\mathbf{4}$ were found to be more potent AChE inhibitor. Molecular docking study of potent AChE inhibitor was performed to find the probable binding mode of the compounds into the active site of receptor. Moreover, the isolated compounds were also screened for in vivo cytotoxicity by brine shrimp lethality assay.
\end{abstract}

Graphical Abstract
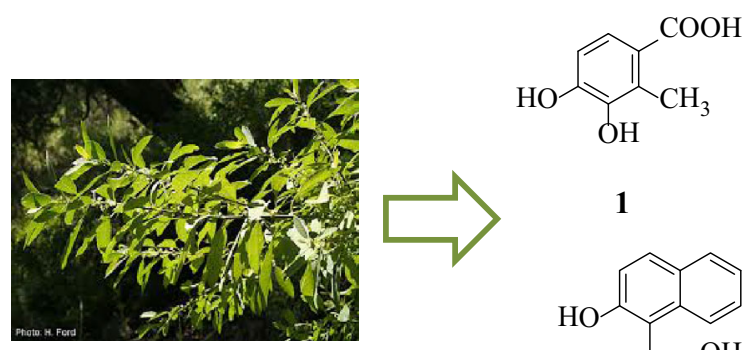

Clutia lanceolata
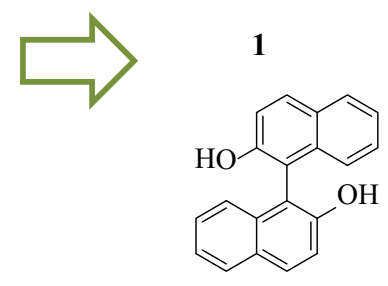

2<smiles>COc1cc(/C=C/C(=O)/C=C(O)/C=C/c2ccc(O)c(OC)c2)ccc1O</smiles>

4<smiles>Cc1cc(O)c2c(c1)C(=O)c1cc(O)cc(O)c1C2=O</smiles>

3

Electronic supplementary material The online version of this article (doi:10.1007/s13659-016-0110-x) contains supplementary material, which is available to authorized users.

M. Parveen $(\bowtie) \cdot$ F. Ahmad · A. M. Malla · S. Azaz Department of Chemistry, Aligarh Muslim University, Aligarh 202002, India

e-mail: mehtab.organic2009@gmail.com

M. Alam

Division of Bioscience, Dongguk University, Gyeongju 780-714,

Republic of Korea
O. A. Basudan

Pharmacognosy, College of Pharmacy, King Saud University, Riyadh 4451, Saudi Arabia

M. R. Silva · P. S. Pereira Silva

CFisUC, Department of Physics, University of Coimbra, 3004-

516 Coimbra, Portugal 


\section{Introduction}

Clutia is a genus of plants belongs to the family Euphorbiaceae and is native to sub-Saharan Africa and the Arabian Peninsula. Ethnobotanical studies have uncovered several Clutia species which are widely used in folk medicine and have potential medicinal value [1]. The phytochemical constituents of the genus Clutia have not been investigated extensively, only few species have been explored phytochemically viz $C$. richardiana [2-7], $C$. abyssinica [8-10], C. robusta [11] and C. similis [12] etc. In this context, Clutia lanceolata, a woody herb or shrub or sometime grown up to tree belonging to the family Euphorbiaceae, is also relatively unexplored. Baka in 2010 showed the antifungal property of the aqueous extracts of its leaves [13] and Mossa et al. reported the hypoglycaemic property of C. lanceolata [14]. As part of our research work to explore the phytochemical and biological profile of medicinal plants $[15,16]$, we have carried out the phytochemical analysis of the leaves of $C$. lanceolata. The present paper reported the isolation, characterization, X-ray crystallographic study and biological activity of four compounds i.e. 3,4-dihydroxy-2-methylbenzoic acid (1), 2,2'-dihydroxy-1,1'-binaphthyl (2), 1,3,8-trihydroxy-6methylanthracene-9,10-dione, Emodin (3) and 5-hydroxy1,7-bis(4-hydroxy-3-methoxyphenyl)hepta-1,4,6-trien-3-one, curcumin (4), isolated from the ethanolic extract of $C$. lanceolata leaves (Fig. 1). The structure of all the isolated phytoconstituents was established on the basis of physical and chemical data (IR, ${ }^{1} \mathrm{H}-\mathrm{NMR},{ }^{13} \mathrm{C}-\mathrm{NMR}$, and MS spectral analysis). However, the structure of compounds 2 and $\mathbf{4}$ was further authenticated with X-ray crystallographic analysis. To the best of our knowledge, these four compounds have not been reported from this plant source. Moreover, compound $\mathbf{2}$ was isolated from the only natural source i.e. the root of Sesbania grandiflora by Noviany et al. [17].

\section{Results and Discussion}

\subsection{Structural Elucidation}

Compound 1 was isolated as brick red crystalline solid, $\mathrm{mp}$ $233-235^{\circ} \mathrm{C}$. Elemental analysis along with the molecular ion peak at $\mathrm{m} / z .168 .04[\mathrm{M}]^{+\cdot}$ agreed with the molecular formula $\mathrm{C}_{8} \mathrm{H}_{8} \mathrm{O}_{4}$. The IR spectrum revealed characteristic absorption bands for hydroxyl group $\left(3336 \mathrm{~cm}^{-1}\right)$ and phenyl ring $\left(1608\right.$ and $\left.1489 \mathrm{~cm}^{-1}\right)$. The presence of phenolic $-\mathrm{OH}$ group was further confirmed with the positive ferric chloride test. The IR spectrum also showed absorption bands at 3463 and $1685 \mathrm{~cm}^{-1}$ corresponded to carboxyl group which was further confirmed by the appearance of effervescences with $\mathrm{NaHCO}_{3}$. The ${ }^{1} \mathrm{H}$ NMR spectrum indicated the presence of two ortho coupled doublets at $\delta 7.74$ and 6.75 corresponding to the H-6 and H-5 aromatic protons, respectively. The downfield shift of proton H-6 is due to the presence of carboxylic group on adjacent carbon. The presence of two singlets at $\delta 10.06$ and 9.67 integrating for two and one proton was corresponded to the two phenolic $-\mathrm{OH}$ and a carboxylic $-\mathrm{OH}$, respectively. Moreover, a sharp singlet at $\delta 2.24$ integrating for three protons indicates the presence of methyl group. The ${ }^{13} \mathrm{C}$ NMR spectrum exhibited peaks at $\delta 13.75$ and
Fig. 1 Structure of isolated compounds (1-4) from Clutia lanceolata<smiles>Cc1c(C(=O)O)ccc(O)c1O</smiles>

Compound 1<smiles>Oc1ccc2ccccc2c1-c1c(O)ccc2cccc(O)c12</smiles>

Compound 2<smiles>Cc1cc(O)c2c(c1)C(=O)c1cc(O)cc(O)c1C2=O</smiles>

Compound 3<smiles>COc1cc(/C=C/C(=O)/C=C(O)/C=C/c2ccc(O)c(OC)c2)ccc1O</smiles>

\section{Compound 4}


178.43 which correspond to the presence of methyl and carbonyl carbon, respectively. Further, peaks at $\delta 148.0$ (C1), 128.3 (C-2), 158.60 (C-3), 158.69 (C-4), 127.98 (C-5) and 114.90 (C-6) showed the presence of six carbons of aromatic ring. In the light of above assignment and by comparing their spectral data and melting points with the reported literature [18], it was concluded that the compound 1 is 3,4-dihydroxy-2-methylbenzoic acid.

Compound 2 was obtained as white crystals, mp $207^{\circ} \mathrm{C}$ with a molecular formula of $\mathrm{C}_{20} \mathrm{H}_{14} \mathrm{O}_{2}$ deduced from the positive ion ESIMS at $m / z$ 286.10 [M] ${ }^{+}$. Elemental analysis was also in good agreement with the molecular formula $\mathrm{C}_{20} \mathrm{H}_{14} \mathrm{O}_{2}$. The UV spectrum of the compound exhibited characteristic absorption band for aromatic nucleus displaying $\lambda_{\text {max }}$ at 227, 278 and $336 \mathrm{~nm}$ indicating the presence of a phenolic chromophore. The IR spectrum showed absorptions at $3425 \mathrm{~cm}^{-1}$ indicating $-\mathrm{OH}$ group, at $3028 \mathrm{~cm}^{-1}$ for aromatic $\mathrm{C}-\mathrm{H}$ stretching and $1380-1615 \mathrm{~cm}^{-1}$ for $\mathrm{C}=\mathrm{C}$ stretching of aromatic rings. The positive response of compound to ferric chloride specifies the phenolic nature of hydroxyl group. The ${ }^{1} \mathrm{H}$ NMR spectrum displayed a singlet at $\delta 11.15$ integrating for two protons corresponded to two hydroxyl group. Two independent ortho-coupled doublets with $J=9 \mathrm{~Hz}$ at $\delta 7.24$ and 7.85 integrating for two protons each corresponded to the $\mathrm{H}-3 / 3^{\prime}$ and $\mathrm{H}-4 / 4^{\prime}$ protons of the A ring of naphthalene. The $\mathrm{H}-5 / 5^{\prime}$ and $\mathrm{H}-8 / 8^{\prime}$ protons of $\mathrm{B}$ ring displayed double doublets with $J=1.3$ and $8.0 \mathrm{~Hz}$ at $\delta 7.94$ and 7.12 , respectively. There were two 3 fold doublets at $\delta 7.38$ and 7.44 corresponded to the remaining protons $\mathrm{H}-6 / 6^{\prime}$ and $\mathrm{H}-7 / 7^{\prime}$ of the naphthyl ring B exhibiting two ortho-couplings $(J=8.0$ and $7.0 \mathrm{~Hz})$ and one meta-coupling $(J=1.3 \mathrm{~Hz})$ doublets, characteristics for the naphthyl ring. The ${ }^{13} \mathrm{C}$ NMR spectrum displayed characteristic peaks of naphthyl ring integrating around at $\delta$ 118.4-133.9. However, the carbon of the connected naphthyl rings showed peaks at $\delta 110.8$ and the carbon with hydroxyl group substitution displayed peak at $\delta 154.8$. In the light of above data it was significantly concluded that compound $\mathbf{2}$ is 2,2'-dihydroxy-1,1'-binaphthyl [17]. The structure of compound $\mathbf{2}$ was further authenticated with the X-ray crystallographic analysis.

Compound $\mathbf{3}$ was isolated as orange coloured solid with $\mathrm{mp}$ of $267-269{ }^{\circ} \mathrm{C}$. Elemental analysis along with the molecular ion peak at $\mathrm{m} / z 270.05[\mathrm{M}]^{+\cdot}$ agreed with the molecular formula $\mathrm{C}_{15} \mathrm{H}_{10} \mathrm{O}_{5}$. The compound responded positively to the ferric chloride test indicating the presence of phenolic-OH group, which further confirmed with the broad peak at $3510 \mathrm{~cm}^{-1}$ in the IR spectrum. The IR spectrum also displayed peak at 3056 and $2918 \mathrm{~cm}^{-1}$ corresponded to aromatic and aliphatic $\mathrm{C}-\mathrm{H}$ stretching vibrations. However, peaks at 1676 and $1625 \mathrm{~cm}^{-1}$ corresponded to $\mathrm{C}=\mathrm{O}$ and $\mathrm{C}=\mathrm{C}$ bonds of $\alpha, \beta$-unsaturated carbonyl functionality. The ${ }^{1} \mathrm{H}$ NMR spectrum of compound showed four meta-coupled doublets at $\delta 7.81,7.65,7.30$ and 7.09 corresponded to aromatic protons $\mathrm{H}-2, \mathrm{H}-4, \mathrm{H}-7$ and $\mathrm{H}-5$, respectively. Singlet at $\delta 12.13$ and 12.02 integrating for two and one protons, respectively, corresponded to hydroxyl protons. Moreover, sharp singlet at $\delta 2.46$ integrating for three protons was assigned to methyl protons. The ${ }^{13} \mathrm{C}$ NMR spectrum exhibited peak for carbonyl carbons at $\delta 182.0$ (C-9) and 192.5 (C10), methyl carbon at $\delta 22.2$, methyl substituted carbons at $\delta$ 149.3 (C-3) and for hydroxyl substituted carbons at $\delta 162.4$ (C-1), 160.3 (C-6) and 162.6 (C-8). The spectrum also showed eight more peaks for aromatic carbons at $\delta 113.7$ (C8a), 121.3 (C-7), 119.9 (C-5), 133.8 (C-5a), 124.5 (C-4), 134.0 (C-4a), 136.9 (C-2) and 111.8 (C-1a). In the light of above data it was significantly concluded that compound $\mathbf{3}$ is 1,3,8-trihydroxy-6-methylanthracene-9,10-dione (Emodin) [19].

Compound 4 was furnished as shining light orange coloured crystals with mp $177^{\circ} \mathrm{C}$. Elemental analysis along with the molecular ion peak at $m / z 368.13[\mathrm{M}]^{+}$ were in good agreement with the molecular formula $\mathrm{C}_{21} \mathrm{H}_{20} \mathrm{O}_{6}$. The IR spectrum showed characteristics peak for $-\mathrm{OH}$ at $3427 \mathrm{~cm}^{-1}$, aromatic and aliphatic $\mathrm{C}-\mathrm{H}$ vibrations at 3065 and $2905 \mathrm{~cm}^{-1}$, respectively. The absorption peaks at 1682, 1480-1605 and $1120 \mathrm{~cm}^{-1}$ corresponded to $\mathrm{C}=\mathrm{O}, \mathrm{C}=\mathrm{C}$ and $\mathrm{C}-\mathrm{O}$ bands, respectively. The ${ }^{1} \mathrm{H}$ NMR spectrum exhibited doublets at $\delta 7.58,7.22$, 6.65 and 6.51 corresponded to H-1, H-2, H-6 and H-7, respectively. However, a sharp singlet at 6.72 was assigned to $\mathrm{H}-4$ proton. The broad singlet at $\delta 11.12$ and 10.75 were assigned to phenolic and enolic hydroxy groups, respectively. The aromatic protons of compound $\mathbf{4}$ showed orthocoupled doublets at $\delta 6.92,6.81$ and singlet at $\delta 7.10$ integrating for two protons each corresponded to $\mathrm{H}-5^{\prime} / 5^{\prime \prime}$, $\mathrm{H}-6^{\prime} / 6^{\prime \prime}$ and $\mathrm{H}-2^{\prime} / 2^{\prime \prime}$, respectively. The methoxy group showed singlet at $\delta 3.85$ integrating for six protons. The ${ }^{13} \mathrm{C}$ NMR spectrum exhibited peaks for aromatic carbons at $\delta 111.2,116.5,121.9,127.8,147.3$ and 149.6 corresponded to $\mathrm{C}-2^{\prime} / 2^{\prime \prime}, \mathrm{C}-5^{\prime} / 5^{\prime \prime}, \mathrm{C}-6^{\prime} / 6^{\prime \prime}, \mathrm{C}-1^{\prime} / 1^{\prime \prime}, \mathrm{C}-3^{\prime} / 3^{\prime \prime}$ and $\mathrm{C}-4^{\prime} / 4^{\prime \prime}$, respectively. Moreover, the straight chain of compound showed peak at $\delta 142.3$ and 124.8 for C-1 and C-2, 140.7 and 122.2 for C-7 and C-6, respectively. However, C-3, C-4 and C-5 displayed peaks at $\delta$ 182.4, 100.1 and 180.3, respectively. In light of the above discussion and with comparison of the data to the reported literature [20], it was concluded that compound 4 is 5-hydroxy-1,7-bis(4-hydroxy-3-methoxyphenyl)hepta-1,4,6-trien-3-one i.e. Curcumin. The structure of compound $\mathbf{4}$ was also authenticated by X-ray crystallographic analysis.

\subsection{Crystal Structure of Compound 2 and $\mathbf{4}$}

Compound $\mathbf{2}$ and $\mathbf{4}$, once isolated were found to be airstable and soluble in all common organic solvents but 
insoluble in water. X-ray crystallographic analysis revealed that compound $\mathbf{2}$ crystallized in the orthorhombic structure with $I b a 2$ space group, while compound $\mathbf{4}$ crystallized in monoclinic crystal system with space group $P 2 / n$. These single crystal X-ray diffraction analysis of compounds 2 and 4 were in good agreement with the previous reports [21-23]. Asymmetric unit of compound $\mathbf{2}$ and $\mathbf{4}$ with the ellipsoids drawn at the $50 \%$ probability level was shown in Figs. 2 and 3, respectively. The crystal data and structure refinement parameters were summarized in Table 1 . The bond lengths and bond angles of compound $\mathbf{2}$ and $\mathbf{4}$ were presented in Tables 2 and 3. The crystal structure of compound 2 was stabilised by the intermolecular $(\mathrm{O}-$ $\mathrm{H}$...O) hydrogen bonding. The bond length of $\mathrm{O} 1-\mathrm{C} 2$ and O2-C12 was 1.375 and $1.351 \AA$, respectively, showed partial double bond character due to the conjugation of lone pair of electrons of oxygen with naphthalene ring. The bond length between two naphthalene rings i.e. $\mathrm{C} 1-\mathrm{C} 11$ was $1.496 \AA$. The dihedral angle between two naphthalene rings $\mathrm{C} 2-\mathrm{C} 1-\mathrm{C} 11$ and $\mathrm{C} 1-\mathrm{C} 11-\mathrm{C} 12$ were $120.2(4)^{\circ}$ and $118.8(4)^{\mathrm{o}}$, respectively. The crystal structure of compound 4 was stabilised by intramolecular $(\mathrm{O}-\mathrm{H} \ldots \mathrm{O})$ hydrogen bonding between $\mathrm{O} 1 \mathrm{H} \ldots \mathrm{O} 5, \mathrm{O} 4 \mathrm{H} \ldots \mathrm{O} 6$ and $\mathrm{O} 3 \mathrm{H} \ldots \mathrm{O} 2$ and intermolecular $(\mathrm{O}-\mathrm{H} . . . \mathrm{O}$ and $\mathrm{C}-\mathrm{H} . . . \mathrm{O})$ hydrogen bonds involving atoms $\mathrm{O} 1 \mathrm{H}$ and $\mathrm{H} 13$ with atoms $\mathrm{O} 3$ and $\mathrm{O} 5$. The $\mathrm{C}-\mathrm{O}$ bond lengths of $\mathrm{O} 1-\mathrm{C} 2, \mathrm{O} 4-\mathrm{C} 17, \mathrm{O} 5-\mathrm{C} 1$ and $\mathrm{O} 6-\mathrm{C} 18$ are in order of $1.36 \AA$ less than typical single $\mathrm{C}-\mathrm{O}$ bonds as the lone pair of electron of oxygen comes in conjugation with benzene ring and thus the $\mathrm{C}-\mathrm{O}$ bonds attain partial double bond character. However, the bond length of O5$\mathrm{C} 23$ and O6-C21 were in order of $1.41 \AA$ and $\mathrm{O} 2-\mathrm{C} 9$ and O3-C11 had 1.29 and $1.28 \AA$, respectively. The C8-C9 and C11-C12 showed single bond character with bond length of $1.45 \AA$ A. However, C9-C10 and C10-C11 showed partial double band character with bond length of 1.38 and $1.40 \AA$. The angles of $\mathrm{C} 8 / \mathrm{C} 9 / \mathrm{C} 10, \mathrm{C} 9 / \mathrm{C} 10 / \mathrm{C} 11$ and $\mathrm{C} 10 / \mathrm{C} 11 / \mathrm{C} 12$

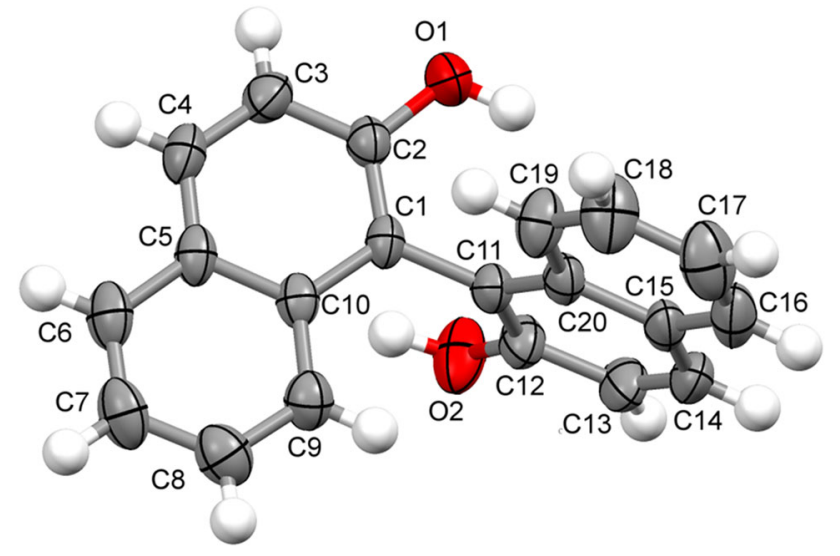

Fig. 2 Asymmetric unit of compound 2 with the ellipsoids drawn at the $50 \%$ probability level were $121.39(12)^{\mathrm{o}}, 120.62(12)^{\mathrm{o}}$ and $124.30(13)^{\mathrm{o}}$, respectively. The dihedral angles of $\mathrm{C} 6 / \mathrm{C} 5 / \mathrm{C} 7 / \mathrm{C} 8$ and $\mathrm{C} 12 / \mathrm{C} 13 /$ C14/C19 were $-4.6(2)^{\circ}$ and $24.7(2)^{\circ}$, respectively.

\subsection{DFT Results of Compounds 2 and 4}

To examine the influence of the intermolecular interactions on the molecular geometries we have performed DFT calculations of the equilibrium geometries of the free molecules starting with the experimental X-ray geometries. For the compound $\mathbf{2}$, there was a good agreement between the experimental and calculated geometries (Table 2; Fig. 4) with the largest difference occurring in the torsion angle $\mathrm{C} 2-\mathrm{C} 1-\mathrm{C} 11-\mathrm{C} 12\left(7.3^{\circ}\right)$, however this was not unexpected, since the rotation around a $\mathrm{C}-\mathrm{C}$ single bond did not have a high energy cost [24]. The situation was quite different for compound 4. In the experimental geometry, there was a high degree of chemical symmetrization in the enol ring, defined as near equality of the $\mathrm{C}-\mathrm{C}$ and $\mathrm{C}-\mathrm{O}$ bond lengths compared pairwise, according to Herbstein et al. [25]. The theoretical geometry did not display this symmetrization. One possible explanation for this discrepancy may be the $\mathrm{O}-\mathrm{H}$...O hydrogen bonds involving the oxygen atoms of the enol ring and hydroxyl groups, that linked different curcumin molecules (Table 3; Fig. 5).

\subsection{AChE Inhibition Results}

The acetylcholinesterase inhibition effect of the isolated compounds (1-4) was assessed by Ellman's spectrophotometric method using human recombinant AChE with tacrine as reference compound. The result obtained has been summarized in Table 4. It can be inferred from the data shown in Table 4, that compound $\mathbf{3}$, exhibited the strongest inhibition to $\mathrm{AChE}$ with an $\mathrm{IC}_{50}$ value of $14.2 \mu \mathrm{M}$, followed by compound $4\left(\mathrm{IC}_{50}=16.4 \mu \mathrm{M}\right), 2$ $\left(\mathrm{IC}_{50}=21.9 \mu \mathrm{M}\right)$ and $\mathbf{1}\left(\mathrm{IC}_{50}=23.7 \mu \mathrm{M}\right)$. The results indicated that all the isolated compounds displayed moderate inhibitory activity against the acetylcholinesterase enzyme. However, compounds $\mathbf{3}$ and $\mathbf{4}$ were found to be more active in comparison to $\mathbf{1}$ and $\mathbf{2}$. This was mainly attributed to the basic skeleton of compound $\mathbf{3}$ and $\mathbf{4}$ which provide them more binding prospects with the formation of hydrogen bonding interactions to the amino acid residues of the protein. However, the $\pi-\pi$ stacking may also leads to improve its activity with the formation of additional nonbonding interactions to the protein.

\subsection{Molecular Docking Studies}

The molecular docking studies were conducted in order to get insight the binding pattern and extent of binding of compounds with the target enzymes. In the present study, 
Fig. 3 Asymmetric unit of compound 4 with the ellipsoids drawn at the $50 \%$ probability level

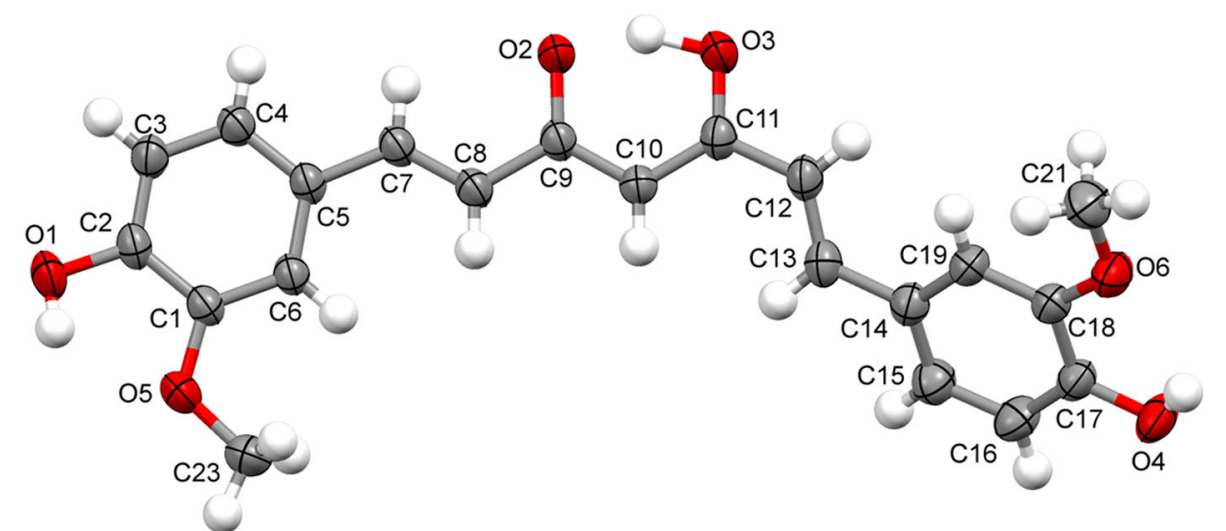

Table 1 Crystal data and structure refinements of compound 2 and 4

\begin{tabular}{|c|c|c|}
\hline & Compound 2 & Compound 4 \\
\hline Empirical formula & $\mathrm{C}_{20} \mathrm{H}_{14} \mathrm{O}_{2}$ & $\mathrm{C}_{21} \mathrm{H}_{20} \mathrm{O}_{6}$ \\
\hline Formula weight & 286.31 & 368.37 \\
\hline Temperature & 293(2) K & 293(2) K \\
\hline Wavelength & $0.71073 \AA$ & $0.71073 \AA$ \\
\hline Crystal system & Orthorhombic & Monoclinic \\
\hline Space group & $I b a 2$ & $P 2 / n$ \\
\hline$a$ & $21.5986(8) \AA$ & $12.6851(5) \AA$ \\
\hline$b$ & $15.6844(6) \AA$ & $7.1848(3) \AA$ \\
\hline$c$ & $8.6243(3) \AA$ & $19.8951(8) \AA$ \\
\hline$\alpha$ & $90^{\circ}$ & $90.00^{\circ}$ \\
\hline$\beta$ & $90^{\circ}$ & $95.223(2)^{\circ}$ \\
\hline$\gamma$ & $90^{\circ}$ & $90.00^{\circ}$ \\
\hline Volume & $2921.58(19) \AA^{3}$ & $1805.71(13) \AA^{3}$ \\
\hline $\mathrm{Z}$ & 8 & 4 \\
\hline Density (calculated) & $1.302 \mathrm{gcm}^{-3}$ & $1.355 \mathrm{gcm}^{-3}$ \\
\hline Absorption coefficient & $0.083 \mathrm{~mm}^{-1}$ & $0.099 \mathrm{~mm}^{-1}$ \\
\hline Extinction coefficient & $0.0052(12)$ & - \\
\hline$F(000)$ & 1200 & 776 \\
\hline Crystal size & $0.53 \times 0.48 \times 0.24 \mathrm{~mm}^{3}$ & $0.60 \times 0.46 \times 0.44 \mathrm{~mm}^{3}$ \\
\hline$\theta$ range for data collection & $3.11-25.84^{\circ}$ & $1.99-29.73^{\circ}$ \\
\hline Index ranges & $-26<h<26 ;-19<k<19 ;-10<l<10$ & $-17<h<13 ;-10<k<10 ;-27<l<27$ \\
\hline Reflections collected & 24389 & 39945 \\
\hline Independent reflections & 2832 & 5076 \\
\hline Completeness to $2 \theta=50^{\circ}$ & $99.8 \%$ & $98.8 \%$ \\
\hline Refinement method & Full matrix LS on $F^{2}$ & Full matrix LS on $F^{2}$ \\
\hline Data/restrains/parameters & $2832 / 1 / 206$ & $5076 / 0 / 255$ \\
\hline Goodness-of-fit on $F^{2}$ & 1.104 & 1.033 \\
\hline Final $R$ indices $[I>2 \sigma(I)]$ & $R=0.0487 ; w R=0.1170$ & $R=0.0487 ; w R=0.1408$ \\
\hline$R$ indices (all data) & $R=0.0781 ; w R=0.1480$ & $R=0.0648 ; w R=0.1570$ \\
\hline Largest diff. peak and hole & 0.163 and -0.204 & 0.342 and -0.301 \\
\hline
\end{tabular}

we have carried out the docking study of the two most potent acetylcholinestrerase inhibitor i.e. compounds $\mathbf{3}$ and 4 of the isolated compounds in order to anticipate the binding mode towards target enzyme (PDB: 1EVE) and to give justification for the observed in vitro AChE inhibition property of the isolated compounds $\mathbf{3}$ and $\mathbf{4}$. The in silico docking experiment for compounds $\mathbf{3}$ and $\mathbf{4}$ against the $\mathrm{X}$-ray crystal structure of receptor (PDB: 1EVE), was 
Table 2 Comparison of selected geometrical parameters for compound 2 as determined by X-Ray diffraction and from the DFT geometry optimization $\left(\AA{ }^{\circ},{ }^{\circ}\right)$

\begin{tabular}{lrr}
\hline & Experimental & DFT \\
\hline O1-C2 & $1.375(5)$ & 1.358 \\
O2-C12 & $1.351(6)$ & 1.358 \\
C1-C11 & $1.496(5)$ & 1.496 \\
C1-C2 & $1.367(6)$ & 1.390 \\
C11-C12 & $1.388(6)$ & 1.390 \\
C1-C2-C3 & $122.1(4)$ & 121.4 \\
C11-C12-C13 & $120.4(4)$ & 121.3 \\
C2-C1-C11 & $120.2(4)$ & 118.9 \\
C1-C11-C12 & $118.8(4)$ & 118.9 \\
C2-C1-C11-C12 & $-88.8(5)$ & -96.1 \\
O1-C2-C3-C4 & $-180.0(4)$ & -180.0 \\
O2-C12-C13-C14 & $-178.4(5)$ & -180.0 \\
\hline
\end{tabular}

Table 3 Comparison of selected geometrical parameters for compound $\mathbf{4}$ as determined by X-Ray diffraction and from the DFT geometry optimization $\left(\AA{ }^{\circ},{ }^{\circ}\right)$

\begin{tabular}{lcc}
\hline & Experimental & DFT \\
\hline O1-C2 & $1.3635(16)$ & 1.3553 \\
O4-C17 & $1.3583(16)$ & 1.3552 \\
O5-C1 & $1.3626(16)$ & 1.3726 \\
O6-C18 & $1.3606(18)$ & 1.3717 \\
O5-C23 & $1.4170(19)$ & 1.4227 \\
O6-C21 & $1.408(2)$ & 1.4237 \\
O2-C9 & $1.2982(17)$ & 1.2554 \\
O3-C11 & $1.2867(18)$ & 1.3290 \\
C8-C9 & $1.4578(17)$ & 1.4721 \\
C9-C10 & $1.3898(18)$ & 1.4403 \\
C10-C11 & $1.4052(18)$ & 1.3793 \\
C11-C12 & $1.4544(18)$ & 1.4590 \\
C1-O5-C23 & $117.42(11)$ & 118.51 \\
C18-O6-C21 & $118.19(12)$ & 118.54 \\
O5-C1-C6 & $125.72(13)$ & 126.21 \\
O6-C18-C19 & $125.18(13)$ & 126.17 \\
C8-C9-C10 & $121.39(12)$ & 117.09 \\
C9-C10-C11 & $120.62(12)$ & 120.75 \\
C10-C11-C12 & $124.30(13)$ & 124.77 \\
C23-O5-C1-C6 & $8.0(2)$ & 0.5 \\
C21-O6-C18-C19 & $5.3(2)$ & 2.1 \\
C6-C5-C7-C8 & $-4.6(2)$ & 0.0 \\
C12-C13-C14-C19 & $24.7(2)$ & 13.9 \\
\hline
\end{tabular}

carried out using PATCHDOCK and iGEMDOCK software. Docking simulations showed comparable binding affinity of compounds $\mathbf{3}$ and $\mathbf{4}$ with AChE enzyme. Several

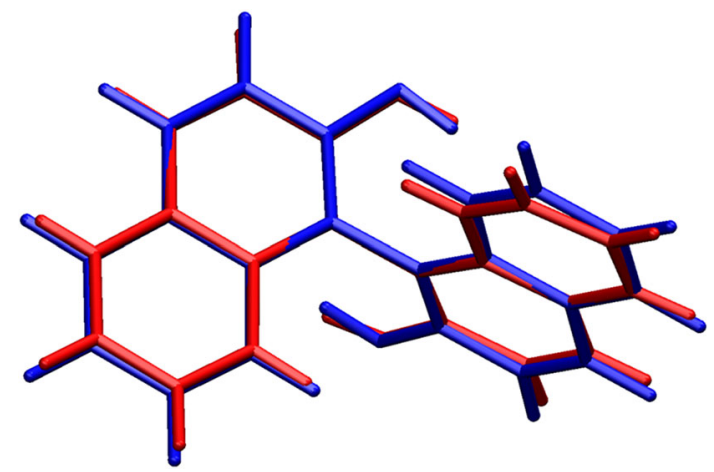

Fig. 4 Comparison of the molecular conformation of compound 2, as established from the X-ray study ( $r e d$ ) with the optimized geometry (blue). (Software used for visualization: VMD, version 1.9.1, January 29, $2012[24])$

interactions from the docking pose were observed notably TYR121; SER122; LEU127; TYR130; GLU199; SER200; PHE330; PHE331 and HIS440 between the receptor and compound 3; SER 122; SER226; CYS231; TRP233; PHE288; VAL323; LEU404 and HIS440 between the receptor and compound 4 in proper binding orientations. The binding score from iGEMDOCK was found to be -108.18 and $-98.91 \mathrm{kcal} / \mathrm{mol}$ for compounds $\mathbf{3}$ and $\mathbf{4}$, respectively. This is due to the cumulative van der Wall contribution and H-bonding interactions. The docking studies revealed that the aromatic ring also plays a major role in stabilizing the ligand-receptor complex by pi-cation interactions with amino acid residue of the target protein as shown in Fig. 6. These strong interactions help the compounds to bury well inside the cavity of target protein and acts as a potent AChE inhibitor. The analysis of enzyme inhibition data obtained from the in vitro experiments, showed the comparative inhibitory property of compound $\mathbf{3}$ $\left(\mathrm{IC}_{50}=14.2 \mu \mathrm{M}\right)$ and compound $4\left(\mathrm{IC}_{50}=16.4 \mu \mathrm{M}\right)$ and found to be moderately potent compared to a standard drug tacrine $\left(\mathrm{IC}_{50}=0.20 \mu \mathrm{M}\right)$, as $\mathrm{AChE}$ inhibitor. The HB plot of the interacted residues in protein of $\mathrm{AChE}$ with compounds 3 and $\mathbf{4}$ was depicted in Fig. 7. This plot helped us to study the way protein residues interacts with ligand.

\subsection{Cytotoxicity Studies}

The in vivo cytotoxicity of compounds (1-4) isolated from the leaves of $C$. lanceolata was evaluated to brine shrimp nauplii using vincristine sulfate as standard (Fig. S1 †ESI). It is one of the most convenient methods to determine the cytotoxicity of any compound. The $\mathrm{LD}_{50}$ value of compounds was reported in ppm units and summarized in Table 5. In the present study the $\mathrm{LD}_{50}$ value of the compounds were found to be $23.40 \mu \mathrm{g} / \mathrm{mL}$ (compound 1), $17.78 \mu \mathrm{g} / \mathrm{mL}$ (compound 2), $13.80 \mu \mathrm{g} / \mathrm{mL}$ (compound 3) and $11.66 \mu \mathrm{g} / \mathrm{mL}$ (compound 4) as compared to the 
Fig. 5 Comparison of the molecular conformation of compound $\mathbf{4}$, as established from the X-ray study (red) with the optimized geometry (blue). (Software used for visualization: VMD, version 1.9.1, January 29, 2012 [24])

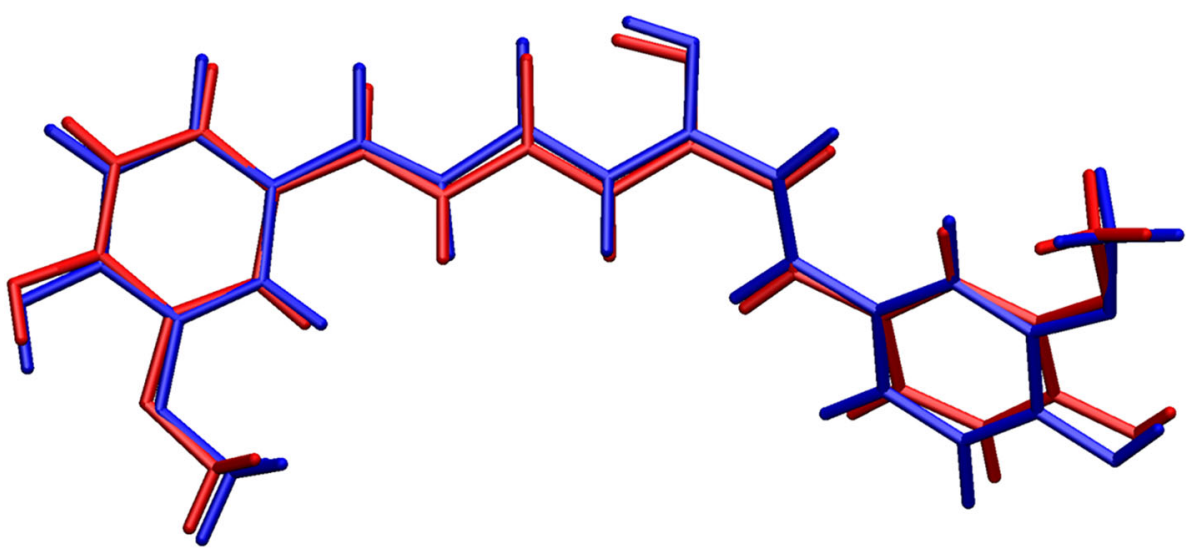

Table 4 In vitro AChE inhibition $\mathrm{IC}_{50}(\mu \mathrm{M})$ of compounds $\mathbf{1 - 4}$ and reference drug tacrine

\begin{tabular}{lll}
\hline S. no. & Compounds & $\begin{array}{l}\mathrm{IC}_{50}(\mu \mathrm{M})^{\mathrm{a}} \pm \mathrm{SEM} \text { for } \\
h \mathrm{AChE} \text { inhibition }\end{array}$ \\
\hline 1 & Compound $\mathbf{1}$ & $23.7 \pm 0.02$ \\
2 & Compound $\mathbf{2}$ & $21.9 \pm 0.05$ \\
3 & Compound $\mathbf{3}$ & $14.2 \pm 0.06$ \\
4 & Compound $\mathbf{4}$ & $16.4 \pm 0.03$ \\
5 & Tacrine (standard) & $0.20 \pm 0.01$ \\
\hline
\end{tabular}

${ }^{\mathbf{a}} \mathrm{IC}_{50}=$ Concentration of inhibitor required to decrease enzyme activity by $50 \%$

standard drug vincristine sulfate whose $\mathrm{LD}_{50}$ was found to be $8.84 \mu \mathrm{g} / \mathrm{mL}$. These data clearly signified the considerable cytotoxicity of all the isolated compounds (1-4). However, compound $\mathbf{4}$ showed most lethality to the brine shrimp than the other isolated compounds 1-3, almost comparable to the standard drug.

\section{Experimental Section}

\subsection{General Experimental Procedures}

All solvents and chemicals were purchased from commercial sources (Sigma-Aldrich, Merck, and others) and used as received or dried using standard procedures. Melting points were determined on a Kofler apparatus and are uncorrected. Elemental analysis (CHN) has been conducted using a Thermo Scientific (FLASH 2000) CHN Elemental Analyser. Fourier transform-infrared (FT-IR) spectra were recorded using a Perkin-Elmer (2000 FTIR) Spectrometer by the $\mathrm{KBr}$ pellet method, values are given in $\mathrm{cm}^{-1}$. The UV spectra were recorded with PerkinElmer UV Win Lab spectrophotometer. ${ }^{1} \mathrm{H}$ and ${ }^{13} \mathrm{C}$ NMR spectra were run in $\mathrm{CDCl}_{3}$ and DMSO- $d_{6}$ on Bruker Avance-II 400 and $100 \mathrm{MHz}$ instruments, respectively. Mass spectra were recorded on a JEOL D-300 mass spectrometer. Thin-layer chromatography (TLC) glass plates were coated with silica gel (E-Merck G254) and exposed to iodine vapour to check the purity of the isolated compounds.

\subsection{Plant Materials}

The leaves of $C$. lanceolata were collected from Abha region of South of Saudi Arabia and identified by Dr. S. Adeen, Taxonomist of the Medicinal, Aromatic and Poisonous Plant Research Centre (MAPPRC), College of Pharmacy, King Saud University, Riyadh, Saudi Arabia. A voucher specimen bearing number 14077 has been deposited in their herbarium.

\subsection{Extraction and Isolation}

The air-dried leaves of $C$. lanceolata were crushed to make powder $(2.0 \mathrm{~kg})$ and extracted exhaustively with $95 \%$ ethanol about three times under reflux temperature and filtered to yield a filtrate. The solvent was evaporated under reduced pressure to afford a crude extract and fractionated successively with petroleum ether, benzene, ethyl acetate and methanol. The petroleum ether and benzene extracts showed similar behaviour on TLC hence were mixed together. The mixed petroleum ether and benzene extract was chromatographed on a silica gel column, eluting stepwise with petroleum ether-benzene $(1: 0,9: 1 \rightarrow 1: 9)$ which afforded compounds $\mathbf{1}$ and $\mathbf{2}$. Similarly, the ethyl acetate extracts was subjected to column chromatography on silica gel, eluting stepwise with benzene-ethyl acetate $(1: 0,9: 1 \rightarrow 1: 9,0: 1)$ which furnished two compounds i.e. compounds 3 and $\mathbf{4}$. The isolated compounds were purified by repeated column chromatography followed by crystallization to get pure compounds.

\subsection{Spectral Characterization of Isolated Compounds}

\subsubsection{3,4-Dihydroxy-2-methylbenzoic acid (1)}

Brick red crystalline solid; mp $233-235^{\circ} \mathrm{C}$; IR $(\mathrm{KBr}) \mathrm{v}_{\max }$ 3463, 3336, 3184, 1685, 1608, 1489, 1431, 1264, 1228, 

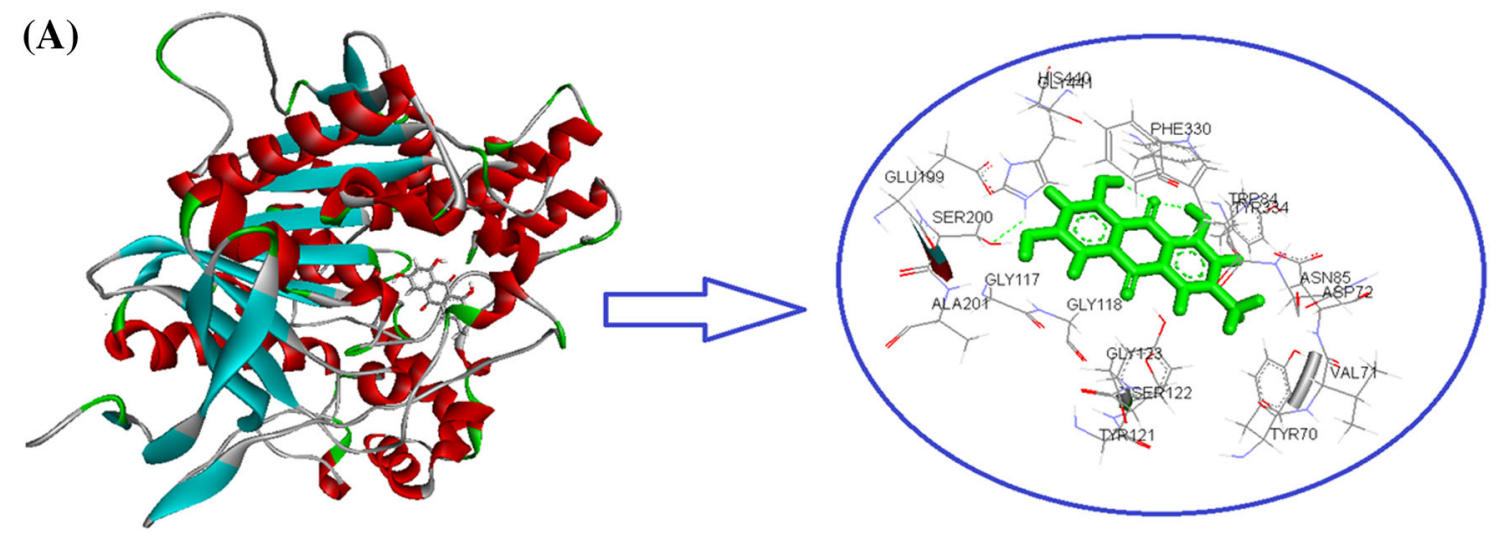

(B)

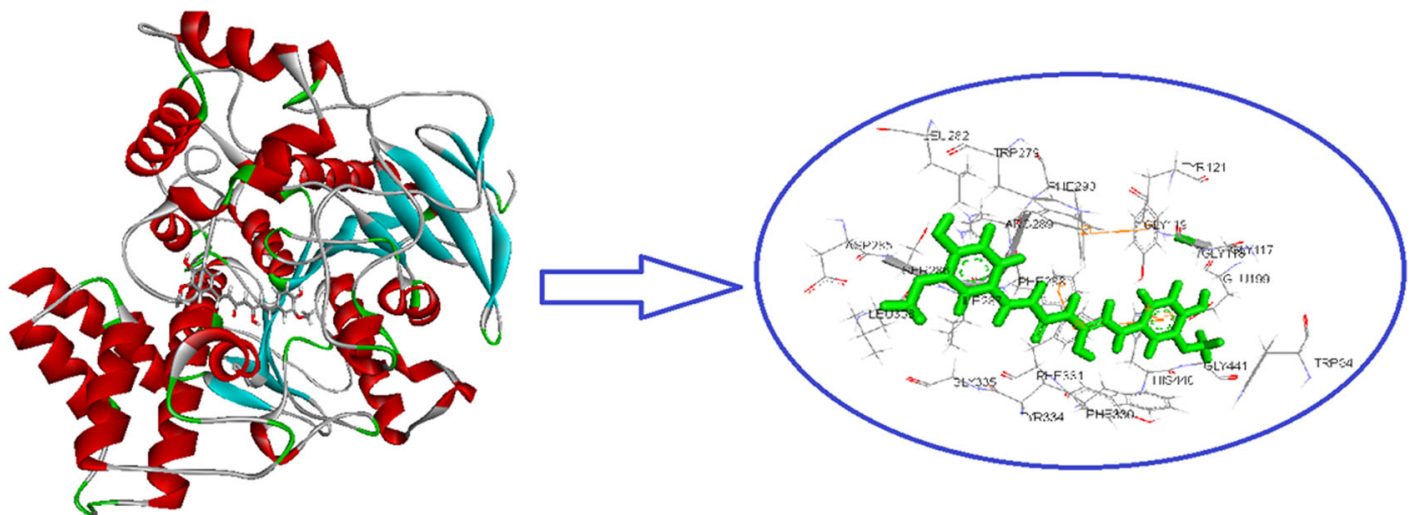

Fig. 6 Interactions profile of a compound 3 and $\mathbf{b}$ compound 4 with receptor

1173, 1089, $827 \mathrm{~cm}^{-1} ;{ }^{1} \mathrm{H}$ NMR (DMSO d $\left.6,400 \mathrm{MHz}\right) \delta$ $10.06(2 \mathrm{H}, \mathrm{s}, 2 \times-\mathrm{OH}), 9.67(1 \mathrm{H}, \mathrm{s},-\mathrm{COOH}), 7.74(1 \mathrm{H}$, $\mathrm{d}, J=8.0 \mathrm{~Hz}, \mathrm{H}-6), 6.75(1 \mathrm{H}, \mathrm{d}, J=8.0 \mathrm{~Hz}, \mathrm{H}-5), 2.24$ $\left(3 \mathrm{H}, \mathrm{s},-\mathrm{CH}_{3}\right) ;{ }^{13} \mathrm{C}$ NMR (DMSO d $\left.6,100 \mathrm{MHz}\right) \delta 178.4(\mathrm{C}$, $\mathrm{COOH}), 158.6$ (C, C-3), 158.6 (C, C-4), 148.0 (C, C-1), 128.3 (C, C-2), 127.9 (CH, C-5), 114.9 (CH, C-6), 13.7 ($\left.\mathrm{CH}_{3}\right)$; ESIMS $m / z, 168.04[\mathrm{M}]^{+\cdot}\left(\mathrm{C}_{8} \mathrm{H}_{8} \mathrm{O}_{4}\right)$; Anal. Calc. for $\mathrm{C}_{8} \mathrm{H}_{8} \mathrm{O}_{4}$ : C, 57.14; H, 4.80; found: C, 58.09; H, 4.95 .

\subsubsection{2,2'-Dihydroxy-1,1'-binaphthyl (2)}

White crystals; mp $207{ }^{\circ} \mathrm{C}$; UV (MeOH) $\lambda_{\max } 227,278$, $336 \mathrm{~nm}$; IR (KBr) $v_{\max } 3425,3382,2971,2918,2840$, $1615,1590,1461,1380,1216,1175,1146,826,750 \mathrm{~cm}^{-1}$; ${ }^{1} \mathrm{H} \mathrm{NMR}\left(\mathrm{CDCl}_{3}, 400 \mathrm{MHz}\right) \delta 11.15(2 \mathrm{H}, \mathrm{s}, 2 \times \mathrm{OH})$, $7.94\left(2 \mathrm{H}, \mathrm{dd}, J=1.3\right.$ and $8.0 \mathrm{~Hz}, \mathrm{H}-5$ and $\left.\mathrm{H}-5^{\prime}\right), 7.85(2 \mathrm{H}$, $\mathrm{d}, J=9.0 \mathrm{~Hz}, \mathrm{H}-4$ and $\left.\mathrm{H}-4^{\prime}\right), 7.44\left(2 \mathrm{H}, \mathrm{m}, \mathrm{H}-7\right.$ and $\left.\mathrm{H}-7^{\prime}\right)$, 7.38 (2H, m, H-6 and H-6'), $7.24(2 \mathrm{H}, \mathrm{d}, J=9.0 \mathrm{~Hz}, \mathrm{H}-3$ and $\left.\mathrm{H}-3^{\prime}\right), 7.12(2 \mathrm{H}, \mathrm{dd}, J=1.3$ and $8.0 \mathrm{~Hz}, \mathrm{H}-8$ and $\left.\mathrm{H}-8^{\prime}\right) ;{ }^{13} \mathrm{C} \mathrm{NMR}\left(\mathrm{CDCl}_{3}, 100 \mathrm{MHz}\right) \delta 154.3(\mathrm{C}, \mathrm{C}-2$ and C-2' $), 133.9$ (C, C-8a and C-8' a), 130.0 (CH, C-4 and C-4' $)$, 129.2 (C, C-4a and C-4' a), 128.2 (CH, C-5 and C-5' $), 126.9$ $\left(\mathrm{CH}, \mathrm{C}-7\right.$ and $\left.\mathrm{C}-7^{\prime}\right), 125.7\left(\mathrm{CH}, \mathrm{C}-6\right.$ and $\left.\mathrm{C}-6^{\prime}\right), 123.5(\mathrm{CH}$, C-8 and C-8 $\left.{ }^{\prime}\right), 118.4\left(\mathrm{CH}, \mathrm{C}-3\right.$ and $\left.\mathrm{C}-3^{\prime}\right), 110.8$ (C, C-1 and
C-1' ${ }^{\prime}$; ESIMS $m / z$ 286.10 [M] ${ }^{+\cdot}\left(\mathrm{C}_{20} \mathrm{H}_{14} \mathrm{O}_{2}\right)$; Anal. Calc. for $\mathrm{C}_{20} \mathrm{H}_{14} \mathrm{O}_{2}$ : C, 83.90; H, 4.93; found: C, 84.88; H, 5.05.

\subsubsection{1,3,8-Trihydroxy-6-methylanthracene-9,10-dione (3)}

Orange coloured crystals; mp $267-269{ }^{\circ} \mathrm{C}$; IR (KBr) $v_{\max }$ 3510, 3056, 2918, 1676, 1625, 1565, 1458, 1371, 1272, 1205, 1161, 1082, 1026, $749 \mathrm{~cm}^{-1} ;{ }^{1} \mathrm{H}$ NMR $\left(\mathrm{CDCl}_{3}\right.$, $400 \mathrm{MHz}) \delta 12.13(2 \mathrm{H}, \mathrm{s}, 2 \times \mathrm{OH}), 12.02(1 \mathrm{H}, \mathrm{s}, \mathrm{OH})$, $7.81(1 \mathrm{H}, \mathrm{d}, J=1.2 \mathrm{~Hz}, \mathrm{H}-2), 7.65(1 \mathrm{H}, \mathrm{d}, J=1.2 \mathrm{~Hz}$, H-4), 7.30 (1H, d, $J=1.2 \mathrm{~Hz}, \mathrm{H}-7), 7.09(1 \mathrm{H}, \mathrm{d}$, $J=1.2 \mathrm{~Hz}, \mathrm{H}-5), 2.46\left(3 \mathrm{H}, \mathrm{s},-\mathrm{CH}_{3}\right) ;{ }^{13} \mathrm{C} \mathrm{NMR}\left(\mathrm{CDCl}_{3}\right.$, $100 \mathrm{MHz}) \delta 192.5(\mathrm{C}=\mathrm{O}, \mathrm{C}-10), 182.0(\mathrm{C}=\mathrm{O}, \mathrm{C}-9)$, 162.6 (C, C-8), 162.4 (C, C-1), 160.3 (C, C-6), 149.3 (C, C-3), 136.9 (CH, C-2), 134.0 (C, C-4a), 133.8 (C, C-5a), 124.5 (CH, C-4), 121.3 (CH, C-7), 119.9 (CH, C-5), 113.7 (C, C-8a), 111.8 (C, C-1a), $22.2\left(\mathrm{CH}_{3}\right)$; ESIMS m/z 270.05 $[\mathrm{M}]^{+\cdot}\left(\mathrm{C}_{15} \mathrm{H}_{10} \mathrm{O}_{5}\right)$; Anal. Calc. for $\mathrm{C}_{15} \mathrm{H}_{10} \mathrm{O}_{5}: \mathrm{C}, 66.67 ; \mathrm{H}$, 3.73; found: C, 67.58; H, 3.85.

\subsubsection{5-Hydroxy-1,7-bis (4-hydroxy-3- methoxyphenyl)hepta-1,4,6-trien-3-one (4)}

Yellow-orange coloured crystals; mp $177{ }^{\circ} \mathrm{C}$; IR (KBr) $v_{\max } 3427,3065,2905,1682,1605,1480,1120 \mathrm{~cm}^{-1} ;{ }^{1} \mathrm{H}$ 
Fig. 7 HB plot of interacted residues in protein with compound $\mathbf{3}$ (a) and compound 4 (b)

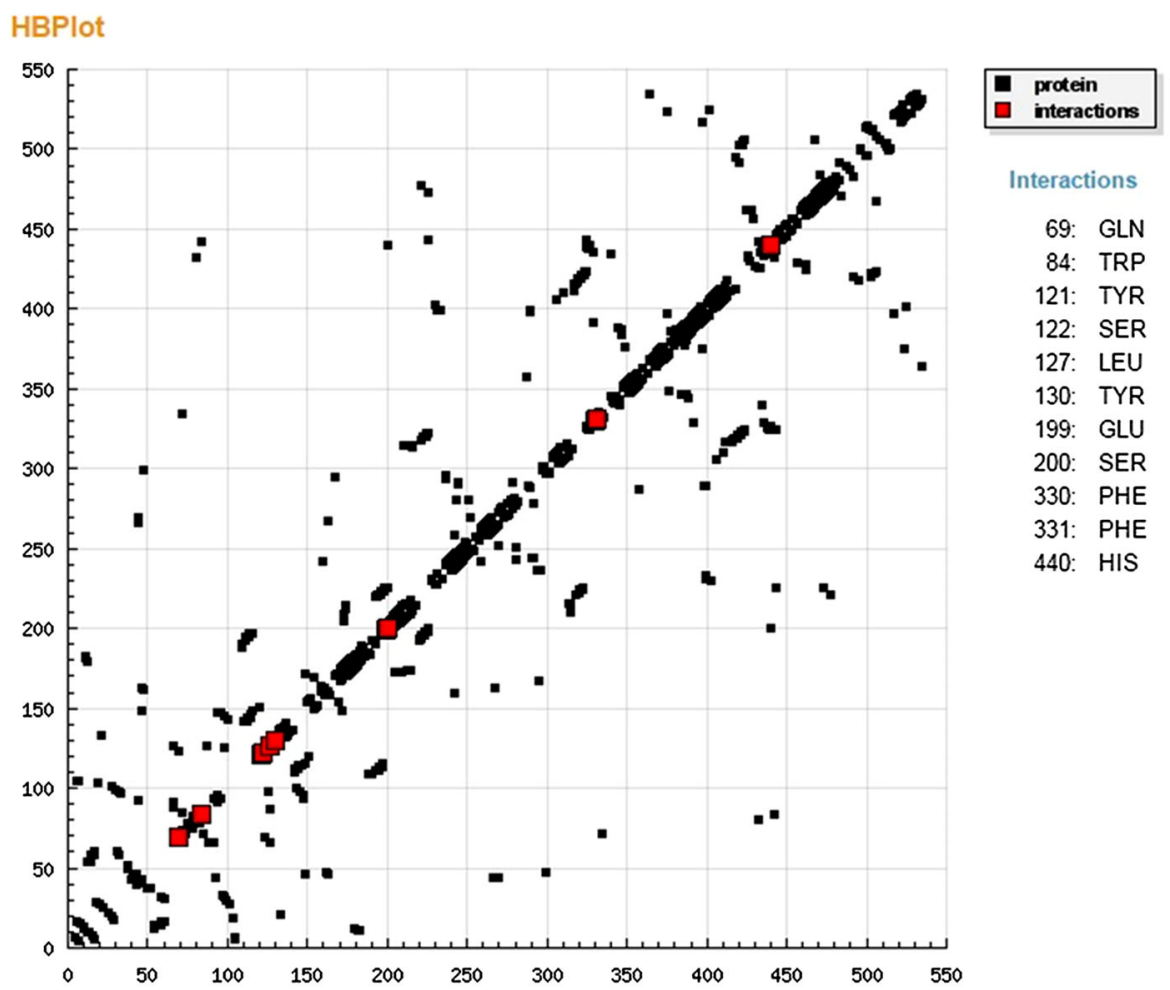

(A)

\section{HBPlot}

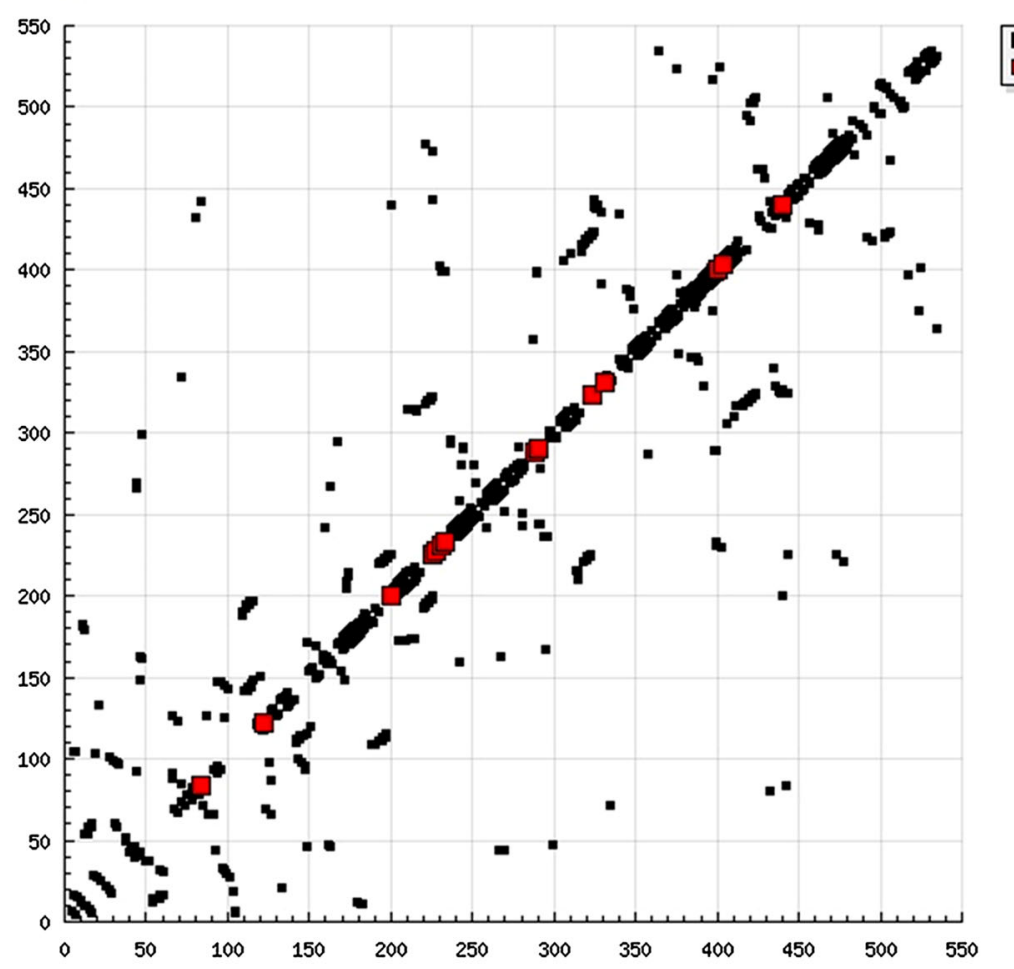

(B)

\begin{tabular}{|c|c|}
\hline Q prot & actions \\
\hline Intera & ctions \\
\hline 84: & TRP \\
\hline 122: & SER \\
\hline $200:$ & SER \\
\hline 226: & SER \\
\hline 228: & SER \\
\hline 231: & CYS \\
\hline 233: & TRP \\
\hline 288: & PHE \\
\hline 290: & PHE \\
\hline 323: & VAL \\
\hline 331: & PHE \\
\hline 400 : & VAL \\
\hline 404: & LEU \\
\hline 440: & HIS \\
\hline
\end{tabular}


Table 5 In vivo cytotoxicity assay of isolated compounds (1-4)

\begin{tabular}{llc}
\hline S. no. & Compound & LD $_{50}$ value $(\mu \mathrm{g} / \mathrm{mL})$ \\
\hline 1 & Compound $\mathbf{1}$ & $23.40 \pm 0.02$ \\
2 & Compound $\mathbf{2}$ & $17.78 \pm 0.05$ \\
3 & Compound $\mathbf{3}$ & $13.80 \pm 0.03$ \\
4 & Compound $\mathbf{4}$ & $11.66 \pm 0.04$ \\
5 & Vincristine sulphate (Standard) & $8.84 \pm 0.01$
\end{tabular}

$\operatorname{NMR}\left(\mathrm{CDCl}_{3}, 400 \mathrm{MHz}\right) \delta 11.12(2 \mathrm{H}, \mathrm{s}, 2 \times-\mathrm{OH}), 10.75$ $(1 \mathrm{H}, \mathrm{s},-\mathrm{OH}), 7.58(1 \mathrm{H}, \mathrm{d}, \mathrm{H}-1), 7.22(1 \mathrm{H}, \mathrm{d}, \mathrm{H}-2), 7.10$ $\left(2 \mathrm{H}, \mathrm{s}, \mathrm{H}-2^{\prime}\right.$ and $\left.\mathrm{H}-2^{\prime \prime}\right), 6.92\left(2 \mathrm{H}, \mathrm{d}, J=8.0 \mathrm{~Hz}, \mathrm{H}-5^{\prime}\right.$ and $\left.\mathrm{H}-5^{\prime \prime}\right), 6.81\left(2 \mathrm{H}, \mathrm{d}, J=8.0 \mathrm{~Hz}, \mathrm{H}-6^{\prime}\right.$ and $\left.\mathrm{H}-6^{\prime \prime}\right), 6.72(1 \mathrm{H}$, s, H-4), $6.65(1 \mathrm{H}, \mathrm{d}, \mathrm{H}-6), 6.51(1 \mathrm{H}, \mathrm{d}, \mathrm{H}-7), 3.85(6 \mathrm{H}, \mathrm{s}$, $\left.2 \times-\mathrm{OCH}_{3}\right) ;{ }^{13} \mathrm{C} \mathrm{NMR}\left(\mathrm{CDCl}_{3}, 100 \mathrm{MHz}\right) \delta 182.4(\mathrm{C}$, C-3), 180.3 (C, C-5), 149.6 (C, C-4' and C-4") 147.3 (C, $\mathrm{C}-3^{\prime}$ and $\left.\mathrm{C}-3^{\prime \prime}\right), 142.3(\mathrm{CH}, \mathrm{C}-1), 140.7(\mathrm{CH}, \mathrm{C}-7), 127.8$ $\left(\mathrm{C}, \mathrm{C}-1^{\prime}\right.$ and $\left.\mathrm{C}-1^{\prime \prime}\right), 124.8(\mathrm{CH}, \mathrm{C}-2), 122.2(\mathrm{CH}, \mathrm{C}-6)$, $121.9\left(\mathrm{CH}, \mathrm{C}-6^{\prime}\right.$ and $\left.\mathrm{C}-6^{\prime \prime}\right), 116.5\left(\mathrm{CH}, \mathrm{C}-5^{\prime}\right.$ and $\left.\mathrm{C}-5^{\prime \prime}\right)$, $111.2\left(\mathrm{CH}, \mathrm{C}-2^{\prime}\right.$ and $\left.\mathrm{C}-2^{\prime \prime}\right), 100.1(\mathrm{CH}, \mathrm{C}-4), 55.6(2 \times-$ $\left.\mathrm{OCH}_{3}\right)$; ESIMS $m / z 368.13[\mathrm{M}]^{+\cdot}\left(\mathrm{C}_{21} \mathrm{H}_{20} \mathrm{O}_{6}\right)$; Anal. Calc. for $\mathrm{C}_{21} \mathrm{H}_{20} \mathrm{O}_{6}$ : C, 68.47; H, 5.47; found: $\mathrm{C}, 69.81 ; \mathrm{H}, 5.85$.

\subsection{X-ray Crystallographic Analysis}

The crystal structures of the compounds $\mathbf{2}$ and $\mathbf{4}$ were determined by X-ray diffraction experiments performed on a Bruker Apex II diffractometer. The diffraction data was collected at room temperature 293(2) K using graphite monochromated Mo K $\alpha(\lambda=0.71073 \AA)$. Data reduction was performed with APEX II [26]. Lorentz and polarization corrections were applied. Absorption corrections were applied using SADABS [27]. An extinction correction was applied during the refinement of the crystal structure of compound 2 [28]. The crystallographic structures were solved using direct methods (SHELXS-97) [28]. The structure refinements were carried out with SHELXL-97 software [28]. The refinements were made by full-matrix least-squares on $F^{2}$, with anisotropic displacement parameters for all non-hydrogen atoms. All the hydrogen atoms were located in a difference Fourier synthesis, placed at calculated positions and then, included in the structure factor calculation in a riding model using SHELXL-97 defaults with the exception of the hydrogen atoms bonded to hetero atoms, which were refined freely. MERCURY 3.3 [29] was used for figure plotting. PLATON [30] was used for data analysis. Additional information to the structures determination is given in Table 1. Atomic coordinates, thermal parameters and bond lengths and angles have been deposited at the Cambridge Crystallographic Data Centre (CCDC) with reference numbers 1463766 and 1463767.

\subsection{DFT Calculations}

The geometry optimizations were performed using the GAMESS package [31], starting from the experimental $\mathrm{X}$-ray geometries. The calculations were performed within density functional theory (DFT) using B3LYP (Becke three-parameter Lee-Yang-Parr) for exchange and correlation, which combines the hybrid exchange functional of Becke [32, 33] with the correlation functional of Lee, Yang and Parr [34]. The calculations were performed with an extended $6-311 \mathrm{G}(\mathrm{d}, \mathrm{p})$ basis set. Tight conditions for convergence of both the self-consistent field cycles and the maximum density and energy gradient variations were imposed ( $10^{-5}$ atomic units). At the end of each geometry optimization we conducted a Hessian calculation to guarantee that the final structure corresponds to a true minimum, using the same level of theory as in the geometry optimization.

\subsection{In Vitro AChE Inhibition Study}

All the isolated compounds (1-4) were assessed for AChE inhibition study by Ellman's method [35, 36]. AChE stock solution was prepared by dissolving human recombinant AChE (EC: 3.1.1.7) lyophilized powder (Sigma-Aldrich) in $0.1 \mathrm{M}$ phosphate buffer $(p \mathrm{H}=8.0)$ containing Triton X-100 $(0.1 \%)$. Five increasing concentrations of test compounds were assayed to obtain $\%$ inhibition of the enzymatic activity in the range of $20-80$. The assay solution consisted of a $0.1 \mathrm{M}$ phosphate buffer $p \mathrm{H} 8.0$, with the addition of $340 \mu \mathrm{M}$ 5,50-dithio-bis(2-nitrobenzoic acid), 0.02 unit per $\mathrm{mL}$ of human recombinant $\mathrm{AChE}$ from human serum and $550 \mu \mathrm{M}$ of the substrate (acetylthiocholine iodide, ATCh). Increasing concentrations of the tested inhibitor were added to the assay solution and pre-incubated for $5 \mathrm{~min}$ at $37{ }^{\circ} \mathrm{C}$ with the enzyme followed by the addition of the substrate. Initial rate assays were performed at $37{ }^{\circ} \mathrm{C}$ using a Jasco V-530 double beam Spectrophotometer. The absorbance value at $412 \mathrm{~nm}$ was recorded for $5 \mathrm{~min}$ and enzyme activity was calculated from the slope of the obtained linear trend. Assays were carried out with a blank containing all components except AChE to account for the non-enzymatic reaction. The reaction rates were compared and the percent inhibition due to the presence of tested inhibitors was calculated. Each concentration was analysed in triplicate, and $\mathrm{IC}_{50}$ values were determined graphically from $\log$ concentration-inhibition curves (GraphPad Prism 4.03 software, GraphPad Software Inc.). Tacrine was used as a standard inhibitor. 


\subsection{Molecular Docking}

Docking simulations of compounds $\mathbf{3}$ and $\mathbf{4}$ were carried out according to the method described previously [37, 38]. The energy minimized structure of compounds $\mathbf{3}$ and $\mathbf{4}$ was sketched with ChemDraw Ultra (2D and 3D). The coordinates of compounds $\mathbf{3}$ and $\mathbf{4}$ was checked using PRODRG program [39] for generating molecular topologies. The three-dimensional structures of target protein function as a receptor (PDB: 1EVE) and was retrieved from the protein data bank. All the heteroatoms coupled with proteins including water molecules, bound ligands and any co-crystallized solvent were discarded from the PDB file and the missing assignments like proper bonds, bond orders, hybridization and charges were assigned using the Molegro Virtual Viewer [40]. PATCHDOCK [41], iGEMDOCK [42] and Acceryl Discovery Studio 4.0 Client [43] were employed to evaluate the molecular docking, energy profile and visualization of compounds-receptor interactions, respectively.

\subsection{In Vivo Cytotoxicity Assay}

Brine shrimp lethality bioassay is commonly used in the bioassay for the bioactive compounds [44, 45]. The in vivo cytotoxicity assay was performed on brine shrimp nauplii (Artemia salina) in accordance with the Mayer method [46]. The egg of brine shrimp were hatched in a tank filled with artificially prepared sea water (brine, $3.8 \% \mathrm{NaCl}$ ) exposed to incandescent light. Air was supplied at the bottom of the tank with the help of air supplier fitted with tube to keep the shrimps in uniform motion. The assay was performed $24 \mathrm{~h}$ after hatching and no food supplement was given during the hatching and experimental periods. A test sample $(5.0 \mathrm{mg})$ was dissolved in $1 \mathrm{~mL}$ DMSO to obtain stock solution of $5 \mathrm{mg} / \mathrm{mL}$. Different concentrations of test samples were obtained from stock solution and placed in separate vials, and the volume of each vial was made up to $5 \mathrm{~mL}$ with brine to obtain the desired final concentrations $(10,20,40,60$ and $80 \mu \mathrm{g} / \mathrm{mL})$. The negative control was prepared in the same manner without the samples. Vincristine sulphate was used as a standard anti-cancer drug. Thirty brine shrimp nauplii were then placed in each vial. After $24 \mathrm{~h}$ of incubation, the vials were observed using a magnifying glass, and the number of survivors in each vial were counted and noted. The $\mathrm{LD}_{50}$ values were calculated using the plot of percentage of mortality and logarithm of concentration. All tests were performed in triplicate and expressed as mean.

\section{Conclusion}

This is the first report of the isolation of these four compounds from Clutia lanceolata leaves viz. 3,4-dihydroxy-2methylbenzoic acid (1), 2,2'-dihydroxy-1,1'-binaphthyl (2), 1,3,8-trihydroxy-6-methylanthracene-9,10-dione (3) and 5-hydroxy-1,7-bis(4-hydroxy-3-methoxyphenyl)hepta-1,4, 6-trien-3-one (4). Molecular structure of compounds 2 and 4 was authenticated unambiguously by X-ray crystallography and DFT studies. All the isolated compounds (1-4) showed significant activity for cytotoxicity and AChE inhibition assay. Compound $\mathbf{4}$ showed significant lethality to the brine shrimp nauplii. As far as AChE inhibition concerned, compounds $\mathbf{3}$ and $\mathbf{4}$ acted as potent enzyme inhibitors. Molecular docking study validated the binding pattern and extent of binding of compounds 3 and $\mathbf{4}$ with the target enzymes.

Acknowledgments Faheem Ahmad thanks the Chairman, Department of Chemistry, AMU, Aligarh, for providing necessary research facilities. UGC is also gratefully acknowledged for research fellowship.

\section{Compliance with Ethical Standards}

Conflict of Interest The authors declare no conflict of interest.

Open Access This article is distributed under the terms of the Creative Commons Attribution 4.0 International License (http:// creativecommons.org/licenses/by/4.0/), which permits unrestricted use, distribution, and reproduction in any medium, provided you give appropriate credit to the original author(s) and the source, provide a link to the Creative Commons license, and indicate if changes were made.

\section{References}

1. R.L.A. Mahunnah, K. Mtotmwema, J. Econ. Tox. Bot. 7, 505 (1985)

2. J.S. Mossa, J.M. Cassady, J.F. Kozlowski, T.M. Zennie, M.D. Antoun, M.G. Pellechia, A.T. McKenzie, S.R. Byrn, Tet. Lett. 29, 3627-3630 (1988)

3. I. Muhammad, J.S. Mossa, M.A. Al-Yahya, H.H. Mirza, F.S. ElFeraly, A.T. Mcphail, Phytochemistry 37, 1377-1381 (1994)

4. I. Muhammad-, J.S. Mossa, H.H. Mirza, F.S. El-Feraly, Phytochemistry 50, 1225-1227 (1999)

5. I. Muhammad, J.S. Mossa, M.A. Al-Yahya, H.H. Mirza, F.S. ElFeraly, J. Nat. Prod. 57, 248-255 (1994)

6. J.S. Mossa, J.M. Cassady, M.D. Antoun, S.R. Byrn, A.T. McKenzie, J.F. Kozlowski, P. Main, J. Org. Chem. 50, 916-918 (1985)

7. J.S. Mossa, I. Muhammad, M.A. Al-Yahya, H.H. Mirza, F.S. ElFeraly, A.T. McPhail, J. Nat. Prod. 59, 224-231 (1996)

8. R.D. Waigh, B. Zerihun, M.R. Euerby, Phytochemistry 29, 2935-2938 (1990)

9. R.D. Waigh, B.M. Zerihun, D.J. Maitland, Phytochemistry 30, 333-335 (1991)

10. B. Zerihun, G.B. Lockwood, R.D. Waigh, J. Nat. Prod. 50, 322 (1986) 
11. P.K. Chepkwony, M. Medina, M. Medina, US Pat. US 8,697,660 B2 (2014)

12. F. Tutin, H.W.B. Clewer, J. Chem. Soc. Trans. 101, 2221-2234 (1912)

13. Z.A.M. Baka, Arch. Phytopath. Plant Prot. 43, 736-743 (2010)

14. J.S. Mossa, M.A. Al-Yahya, I.A. Al-Meshal, Medicinal plants of Saudi Arabia (King Saud University Press, Riyadh, 2000)

15. M. Parveen, A.M. Malla, M. Alam, F. Ahmad, P.S.P. Silva, M.R. Silva, Nat. Prod. Res. 28, 646-652 (2014)

16. M. Parveen, F. Ahmad, A.M. Malla, M.S. Khan, S.U. Rehman, M. Tabish, M.R. Silva, P.S.P. Silva, J. Photochem. Photobiol. B 159, 218-228 (2016)

17. Noviany, H. Osman, W.K. Chong, K. Awang, N. Manshoor, J. Basic Appl. Sci. 8, 253-256 (2012)

18. A.J. Aladesanmi, S.A. Odediran, Fitoterapia 71, 179-182 (2000)

19. D. Nandani, R.N. Verma, A. Batra, Ann. Phytomed. 2, 96-104 (2013)

20. M. Nabati, M. Mahkam, H. Heidari, Iran. Chem. Commun. 2, 236-243 (2014)

21. F. Toda, K. Tanaka, H. Miyamoto, H. Koshima, I. Miyahara, K. Hirotsu, J. Chem. Soc. Perkin Trans. 2, 1877-1885 (1997)

22. S.P. Parimita, Y.V. Ramshankar, S. Suresh, T.N.G. Row, Acta Crystallogr. E 63, o860-o862 (2007)

23. P. Sanphui, N.R. Goud, U.B.R. Khandavilli, S. Bhanoth, A. Nangia, Chem. Commun. 47, 5013-5015 (2011)

24. D. Buttar, M.H. Charlton, R. Docherty, J. Starbuck, J. Chem. Soc. Perkin Trans. 2, 763-772 (1998)

25. F.H. Herbstein, B.B. Iversen, M. Kapon, F.K. Larsen, G.K.H. Madsen, G.M. Reisner, Acta Crystallogr. B 55, 767-787 (1999)

26. Bruker, APEX2 and SAINT, Bruker AXS Inc., Madison, Wisconsin, USA (2003)

27. G.M. Sheldrick, SADABS (University of Gottingen, Germany, 2003)

28. G.M. Sheldrick, Acta Crystallogr. A 64, 112-122 (2008)
29. C.F. Macrae, P.R. Edgington, P. McCabe, E. Pidcock, G.P. Shields, R. Taylor, M. Towler, M. van deStreek, J. Appl. Crystallogr. 39, 453-457 (2006)

30. A.L. Spek, Acta Crystallogr. D 65, 148-155 (2009)

31. M.W. Schmidt, K.K. Baldrige, J.A. Boatz, S.T. Elbert, M.S. Gordon, J.J. Jensen, S. Koseki, N. Matsunaga, K.A. Nguyen, S. Sue, T.L. Windus, M. Dupuis, J.A. Montgomery, J. Comput. Chem. 14, 1347-1363 (1993)

32. A.D. Becke, Phys. Rev. A 38, 3098-3100 (1988)

33. A.D. Becke, J. Chem. Phys. 98, 5648-5652 (1993)

34. C. Lee, W. Yang, R.G. Parr, Phys. Rev. B 37, 785-789 (1988)

35. G.L. Ellman, K.D. Courtney, V.J. Andres, R.M.F. Stone, Biochem. Pharmacol. 7, 88-95 (1961)

36. M. Parveen, F. Ahmad, A.M. Malla, S. Azaz, New J. Chem. 39, 2028-2041 (2015)

37. F. Ahmad, M. Parveen, M. Alam, S. Azaz, A.M. Malla, M.J. Alam, D.U. Lee, S. Ahmad, J. Mol. Str. 1116, 317-332 (2016)

38. M. Parveen, F. Ahmad, A.M. Malla, M. Alam, D.U. Lee, Catal. Lett. 144, 2091-2106 (2014)

39. A.W. Schuttelkopf, D.M.F.V. Aalten, Acta. Crystallogr. D 60, 1355-1363 (2004)

40. R. Thomsen, M.H. Christensen, J. Med. Chem. 49, 3315-3321 (2006)

41. D.S. Duhovny, Y. Inbar, R. Nussinov, H.J. Wolfson, Nucleic Acids Res. 33, 363-367 (2005)

42. J.M. Yang, C.C. Chen, Proteins Struct. Funct. Bioinform. 55, 288-304 (2004)

43. Accelrys Software Inc, Discovery Studio Modeling Environment Releaser 4.0 (Accelrys Software Inc, SanDiego, 2013)

44. G.X. Zhao, Y.H. Hui, J.K. Rupprecht, J.L. McLaughlin, K.V. Wood, J. Nat. Prod. 55, 347-356 (1992)

45. I.J. Bulbul, Y. Begum, Sci. Res. J. 2, 15-20 (2014)

46. B.N. Mayer, N.R. Ferrigni, J.E. Putnam, L.B. Jacobsen, D.E. Nichols, J.L. McLaughlin, Planta Med. 45, 31-34 (1982) 